\title{
Awareness level on the relevance of forensics in criminal investigation in Nigeria
}

\section{Omorogbe Owen Stephen ${ }^{1}$, Orhue Osazee Kelvin², Ehikhamenor Edeaghe ${ }^{3}$ and Nwawuba Stanley Udogadi ${ }^{3 *}$}

\author{
${ }^{1}$ Department of Oral and Maxillofacial Surgery, University of Benin Teaching Hospital, Benin City, \\ Edo State, Nigeria \\ ${ }^{2}$ Department of Family Dentistry, University of Benin Teaching Hospital, Benin City, Edo State, \\ Nigeria \\ ${ }^{3}$ Centre for Forensic Programmes and DNA Studies, University of Benin, Benin City, Edo State, \\ Nigeria
}

\section{Abstract}

The main aim of forensic science is to gather intelligence to enable the judge to credible and logical decisions in the court by means of scientific approach through evaluation of evidence for the administration of justice, and country around the world now considers forensic methodology as the gold standard for criminal investigation. Therefore, the present study examined the level of awareness on the relevance of forensics in criminal investigation in Nigeria. The design used in this study is the survey research design and the sample size of this study was a total of one hundred personnel of law enforcement and the judiciary. The study adopted descriptive statistics which involves the use of frequency and percentage. The result of the present study revealed that the participants were distributed socio-demographically as follows; there was an observable higher number of male participants (68\%) relative to the female participants $(32 \%)$, As per age distribution, a larger population of the participants were found to be $>40$ years of age with $55 \%$, and it was observed that age between $35-39$ years ranked the least with $15 \%$. On educational level, the result of the present study revealed that majority of the participants possesses a bachelor's degree as the highest level of educational qualification with $75 \%$ from a pool of $100 \%$ of participants. The present study further examined responses on the relevance of forensics in criminal investigation, and the result revealed an inadequate level of awareness on the relevance of forensics in criminal investigation. Therefore, the study recommends that the Nigerian Police Force and the Judiciary should collaborate with Universities running programs on forensics for trainings.

\section{More Information}

*Address for Correspondence:

Nwawuba Stanley Udogadi, Centre for Forensic Programmes and DNA Studies, University of Benin, P.M.B. 1154, Benin City, Nigeria, Email: nwawubastanley@gmail.com; omorogbeteveo@gmail.com

Submitted: September 28, 2021
Approved: October 14, 2021

Published: October 15, 2021

How to cite this article: Stephen OO, Kelvin OO, Edeaghe E, Udogadi NS. Awareness level on the relevance of forensics in criminal investigation in Nigeria. J Forensic Sci Res. 2021; 5: 053-057.

DOI: 10.29328/journal.jfsr.1001028

ORCiD: orcid.org/0000-0003-0848-3791

Copyright: ( 2021 Stephen OO, et al. This is an open access article distributed under the Creative Commons Attribution License, which permits unrestricted use, distribution, and reproduction in any medium, provided the original work is properly cited.

Keywords: Forensics; Forensic in Nigeria; Forensic evidence; Relevance of forensics and crime in Nigeria

Check for updates

(8) OPEN ACCESS

\section{Introduction}

Forensic science can be considered as the appliance of natural, physical, and social sciences to matters of the law. Most forensic scientists hold that investigation begins at the scene, irrespective of their associated field [1]. Appropriate investigation, collection, and preservation of evidence are vital for fact-finding and for guaranteeing suitable evaluation and interpretation of the evidence, regardless of its nature [1]. Forensic science, a multidisciplinary profession draws principal from chemistry and biology, but also psychology and social sciences. Its relevance within the criminal justice system cannot be overstated, owing to the fact that the necessity for a crime-free, peaceful, habitable and developed society continually subsists [2]. The activities of the forensic scientists include; DNA profiling or matching, fingerprint analysis, blood spatter analysis, crime scene investigation and a host of others. However, the primary objective of forensics is to provide intelligence to enable the judge to credible and logical decisions in court by means of scientific method through evaluation of evidence for the administration of justice [3].

In a country like Nigeria where criminal activities have been reported to be on the increase, and the government seems helpless in part due to the sophistication in terms of how such crimes are perpetrated, the need for modern approach of criminal investigation continue to beckon [4]. A body of reports by security experts has associated cases of unsolved crimes that dot the Nigeria criminal justice system to the 
absence of forensic approach. This forensic gap has rendered justice quite prolonged and unproductive [4]. In Nigeria, heinous crimes including murder still continue to be unsolved by the criminal justice system in part as a result of the dearth in forensics. Nigeria security personnel are largely dependent on eye witness testimonies or confessions, and where any of the two fails, a combination of the two is considered a systematic and exhaustive investigation [5]. While, the central source of evidence; forensics which is dependable, authentic, concrete and productive are underutilized [5]. The present situation poses a serious dent on the forensic investigative capacity of the Nigerian police and other such security agencies.

The identification of murder suspects remains a critical element in forensic investigation $[5,6]$. The role of forensic science services within the administration of justice starts at the crime scene with the identification and recovery of physical evidence. It then proceeds with the investigation and the assessment of the evidence in a laboratory, and the presentation of the findings to judges, prosecutors, lawyers and others for expedition of administration of justice. For insurance of the evidence integrity, it is necessary that a maximum chain of custody is maintained and also all parties involved from the first responder to the end-users of the provided evidence should be well informed of the forensic process, and the specialized services provided by forensic laboratories $[7,5]$. Forensic science provides various possibilities that can assist in trailing and arresting perpetrators of criminal acts by agents of the criminal justice system. The role of forensic science is changing from an auxiliary role to the playmaker in many categories of criminal investigation, providing rapid, unbiased and reliable information on crime and suspects [8].

An extensive literature search revealed a dearth in research report on forensics in Africa, particularly Nigeria. However, a few studies have reported that there is substantial progression towards the use of forensics technology in criminal investigation resulting to a significant increase in the level of awareness on the relevance of forensics in criminal investigation in some African countries including South Africa, Egypt and Botswana [9-11]. In Nigeria, it has been observed that there is a state of privation of forensic skills which negatively impact the investigative competence of the law enforcement agent [4]. To this backdrop, our previous study Nwawuba and Akpata [12] revealed an inadequate level of awareness on the role of forensics in criminal investigation in Nigeria. However, in attempt to grow the knowledge on the relevance of forensics and the need for the creation of a forensic council in Nigeria, it became necessary to examine the level of awareness on the relevance of forensics in criminal investigation which would be a chaperon for proposing bills for the adoption of forensics technology as a gold standard in criminal investigation in Nigeria.

\section{Methodology}

\section{Research design}

This study adopted the survey research design whereby- the entire population of the study were sampled through the administration of the questionnaire to the selected research participants of the total population. This design was considered appropriate because it can easily be used to reach a large population easily.

\section{Population of the study and sample size}

The sample population of the present study was one hundred. The sample population was drawn from two categories using the stratified random sampling technique, the categories include the judiciary arm and the law enforcement. This is because the selected categories are involved in criminal investigation.

\section{Method of data analysis}

The study adopts descriptive statistics which involves the use of frequency and percentage.

\section{Results}

\section{Socio-demographic information}

The result of the present study on socio-demographic information (Table 1) revealed that, from the study population of 100 participants, there was an observable higher number of male participants (68\%) relative to the female participants (32\%). As per age distribution, a larger population of the participants were found to be $>40$ years of age with $55 \%$, and it was observed that age between 35-39 years ranked the least with $15 \%$. Considering the educational background of the participants, the result revealed that majority of the participants possesses a bachelor's degree as the highest level of educational qualification with $75 \%$, while $26 \%$ of the participants were found to possess less than tertiary education. In respect of the profession, the result of the study revealed that $55 \%$ of the participants were law enforcement agents (Nigerian Police), and 45\% were found to the judiciary (Lawyers and Judges).

\section{Relevance of forensics in criminal investigation}

The present study further examined the awareness level on the relevance of forensics in criminal investigation as presented in Figures 1-6. the result on have you heard about

\begin{tabular}{|c|c|c|}
\hline \multicolumn{2}{|l|}{ Table 1: Showing Socio-Demographic Information. } \\
\hline Variables & Frequency & Percentage \\
\hline Gender & & 68 \\
\hline Male & 68 & 32 \\
\hline Female & 32 & \\
\hline Age (Years) & & 30 \\
\hline $30-34$ & 30 & 15 \\
\hline $35-39$ & 15 & 55 \\
\hline$>40$ & 55 & 26 \\
\hline Educational Level & & 74 \\
\hline Less than tertiary education & 26 & \\
\hline Bachelor & 74 & 55 \\
\hline Occupation & & 55 \\
\hline Law Enforcement & 55 & \\
\hline Judiciary & 45 & \\
\hline
\end{tabular}




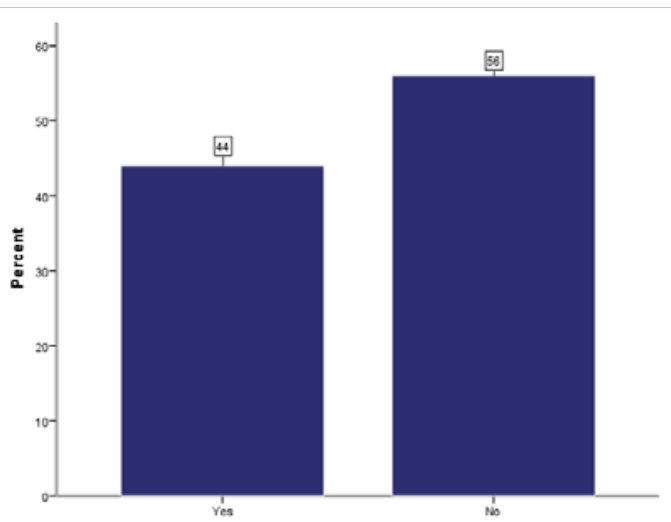

Figure 1: Showing responses on have you heard about forensics.

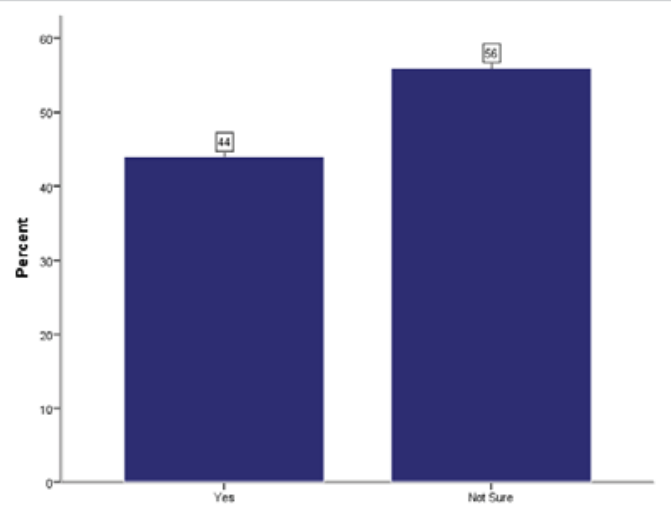

Figure 2: Showing responses on can forensics methodology be used for criminal investigation in Nigeria.

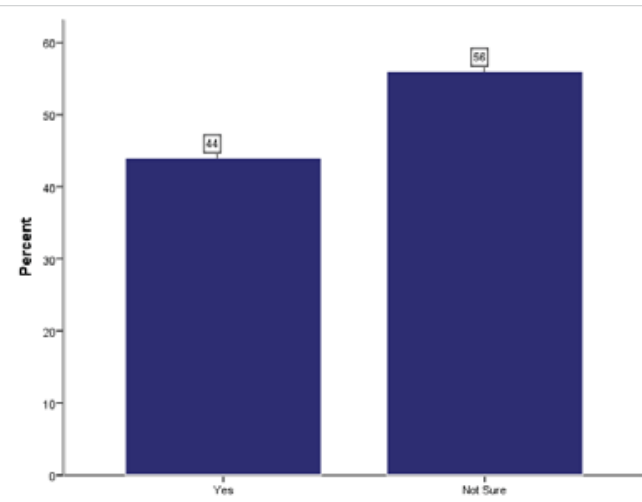

Figure 3: Showing responses on does forensics provide irrefutable evidence for the administration of justice.

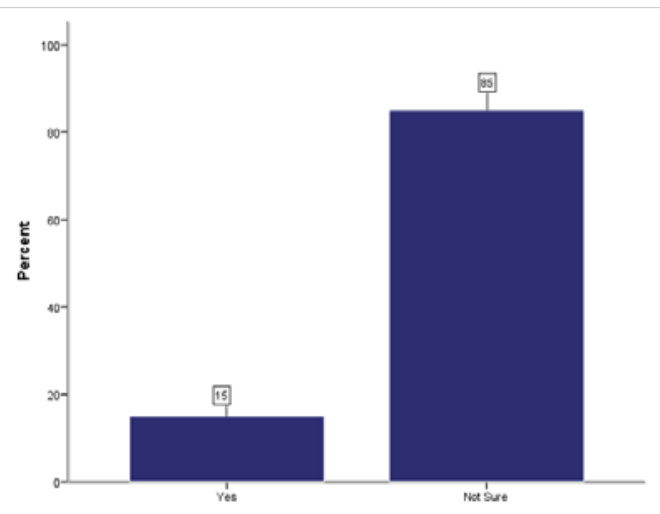

Figure 4: Showing responses on does Nigeria courts accepts forensic evidence.

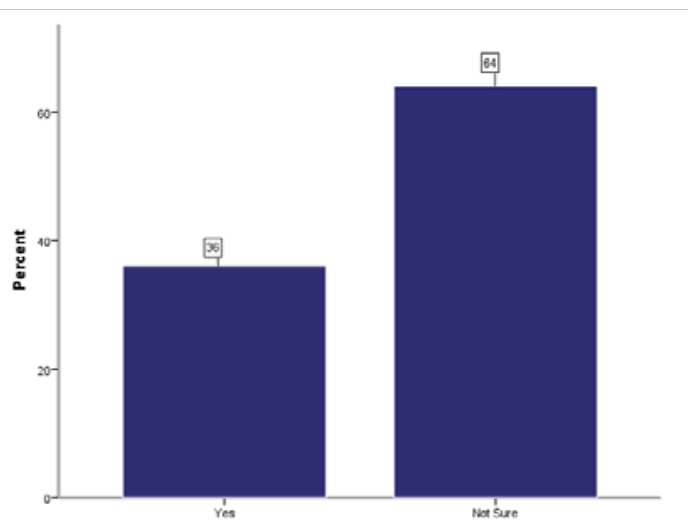

Figure 5: Showing responses on would forensics contribute to the reduction of crimes in Nigeria.

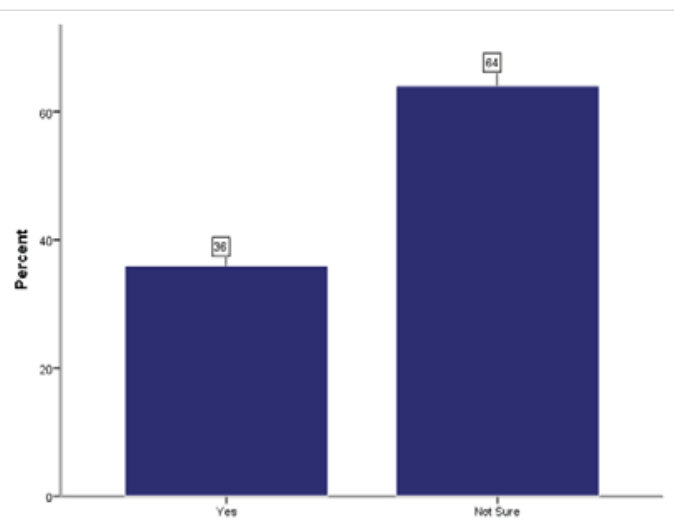

Figure 6: Showing responses on can forensics be used to tackle the upsurge of crime in Nigeria.

forensics (Figure 1) revealed that, a greater population (56\%) of the participants from a pool of $100 \%$ had no knowledge about forensics, and only $46 \%$ of the population demonstrated adequate knowledge of forensics. The same trend was also observed on can forensic methodology be used for criminal investigation in Nigeria (Figure 2) as well the responses on does forensics provide irrefutable evidence for the administration of justice (Figure 3) with 56\% (Not Sure) and $46 \%$ (Yes). As per the responses on do Nigeria courts accepts forensic evidence, the result as demonstrated in Figure 4 revealed that a larger proportion of the participants were not sure (85\%) while only 15\% (Yes) demonstrated adequate knowledge on the position of forensic evidence in the Nigeria justice system. Finally, responses on would forensics contribute to the reduction of crimes in Nigeria, and can forensics be used to tackle the upsurge of crime in Nigeria as shown in Figures $5 \& 6$ followed similar trend with $64 \%$ of the participants reporting (Not Sure) and only 36\% from the pool of $100 \%$ reported with a (Yes).

\section{Discussion}

Forensics is regarded as one of the fundamentals of the criminal justice system. It basically deals with the examination of scientific and physical evidences gathered from the crime scene. The need for the application of this Science in criminal investigation arose because our society has been undergoing 
drastic societal changes at a very rapid pace [13]. Over the years, there have been an observable paradigm shift from the old mode of criminal investigation to a modern approach. Criminal elements are also adept to sophisticated methods and as such, there is an increasing need for forensics. It is vital, owing to the fact that when scientific methods and approach are used there is not much possibility for any biases or injustices [13]. Hence, the present study examined the level of awareness on the relevance of forensics in criminal investigation in Nigeria with focus on professionals that have been demonstrated to have adequate knowledge on the application of forensics in the criminal justice system in Nigeria as reported in the study of [12].

The result of the present study on socio-demographic characteristics (Table 1) revealed the there was an observable higher number of male participants $(68 \%)$ relative to the female participants (32\%). Our result on gender distribution corroborates similar report of Nwawuba and Akpata [12] and Oguntunde [14]. As per age distribution, a larger population of the participants were found to be $>40$ years of age with $55 \%$, and it was observed that age between 35-39 years ranked the least with $15 \%$. On educational level, the result of the present study revealed that majority of the participants possesses a bachelor's degree as the highest level of educational qualification with $75 \%$ from a pool of $100 \%$ of participants, while $26 \%$ of the participants was found to possess less than tertiary education as the highest qualification. In respect of the profession of the participants, the result of the study revealed that $55 \%$ of the participants were law enforcement agents (Nigerian Police), and $45 \%$ were found to the judiciary (Lawyers and Judges). The inclusion criteria of participants (Law enforcement and Judiciary), is as a result of their involvement in criminal investigation. Clearly, the criminal justice system (CJS) is an essential part of any civilized nation to ensure justice, fairness, the practice of the rule of law and the institutionalization of a democratic system [15]. Going forward, a criminal justice system is a system made up of different agents charged with the responsibilities of investigating and prosecuting criminal cases and the system envisages the law enforcement, and judiciary as its components $[15,16]$. Correspondingly, body of evidence has revealed that the law enforcement and the judiciary collaborate with forensic scientist in criminal investigation [11,12], hence the study focused on examining the two profession on the level of awareness on the relevance of forensics in criminal investigation.

The present study further examined the awareness level on the relevance of forensics in criminal investigation. the result (Figure 1) revealed that, a greater population (56\%) of the participants from a pool of 100 had no knowledge about forensics, and only $46 \%$ of the population demonstrated adequate knowledge of forensics. Our finding corroborates the finding of Nwawuba and Akpata [12] on inadequate level of awareness on the role of forensics in criminal investigation.
However, Studies around the world have demonstrated an increased level of awareness on the relevance of forensics in criminal investigation in developed countries [17-19]. In the same light, some African countries including South Africa, Egypt, Morocco, Namibia, Botswana, and Sudan have also demonstrated awareness on the important position of forensics in their respective criminal justice system $[9,20,21]$. The same trend on inadequate level of awareness was also observed on can forensic methodology be used for criminal investigation in Nigeria (Figure 2) as well the responses on does forensics provide irrefutable evidence for the administration of justice (Figure 3) with 56\% (Not Sure) and $46 \%$ (Yes). one of the primary objectives of forensics, appears to be gathering of intelligence to enable the judge to credible and rational decisions in the court by means of scientific approach via evaluation of evidence for the administration of justice, and country around the world now considers forensic methodology as the gold standard for criminal investigation $[3,11,22]$.

Additionally, forensics facilitates criminal investigation in all varied facets and plays the pivotal role in keeping law and order in a society, and in today's world the use of forensic evidence and the application of forensic sciences form an integral part of the criminal investigation system and prosecutions [23]. Going forward, the result (Figure 4) of the responses on do Nigeria courts accepts forensic evidence revealed that a larger proportion of the participants were not sure $(85 \%)$ while only $15 \%$ (Yes) demonstrated adequate knowledge on the position of forensic evidence in the Nigeria justice system. This result agrees to the assertion that there is dearth in knowledge on forensics as well as the laws that allows for acceptance of forensic evidence in the Nigerian courts $[5,24]$. In practice, the Nigerian courts are positioned to accept evidence relating to the use of scientific evidence, and the person empowered to present such evidence is viewed as an expert witness as contained in Evidence Act 2011, s 68 $[25,26]$.

Finally, responses on would forensics contribute to the reduction of crimes in Nigeria, and can forensics be used to tackle the upsurge of crime in Nigeria as shown in Figures 5 \& 6 followed similar trend with $64 \%$ of the participants reporting (Not Sure) and only 36\% from the pool of $100 \%$ reported with a (Yes). The relevance of forensics in the criminal investigation cannot be overstated, as the need to have a crime-free, nonviolent, livable and developed society constantly subsists [2]. Regardless of the severity of a criminal case, it has been proven that forensics continues to be a reliable workhorse for criminal investigation, and the result of forensic investigation can make the difference between the acquittal and conviction in the court of law [23]. It is unbelievable that with the advancement of technologies for forensics in crime investigation, the Nigerian Police Force still to a great extent relies on traditional investigative techniques for criminal investigation [5]. The present-day Nigeria is 
confronted with security challenges and it has been revealed that criminals have also become adept in their operations, and the peculiarity of the various forms of perpetrated crimes in Nigeria tends to involve or leave behind biological evidence at the scene of a crime. These pieces of biological evidence are a key sample for DNA profiling and subsequent storage in a forensic DNA database [26]. Hence, a switch to a modern approach of criminal investigation "forensics" has become very necessary to detect, apprehend, and enhance the administration of justice.

\section{Conclusion}

The result of the present study revealed an inadequate level of awareness on the relevance of forensics in criminal investigation. Therefore, the study recommends that the Nigerian Police Force and the Judiciary should collaboration with Universities running programs on forensics for trainings.

\section{References}

1. Marasa MH, Miranda MD. Forensic Science. Encyclopedia of Law and Econ. 2014; 1-6.

2. Ladapo OA. Effective investigations, a pivot to efficient criminal justice administration: Challenges in Nigeria. Afr J Crim Justice Stud. 2011; 5: 79-94.

3. Cardinetti B, Cammarota C. Negative Conclusion Cases: A Proposal for Likelihood Ratio Evaluation. Law Probability and Risk. 2005; 4: 79-88.

4. Ngboawaji D. An Evaluation of the Challenges of Forensic Investigation and Unsolved Murders in Nigeria. Afr J Crim Justice Stud. 2012; 6: 143-162.

5. Alisigwe OJ, Oluwafemi OM. The State of Forensic Science in Crime Investigation and Administration of Justice in Nigeria. Int J Sci Eng Res. 2019; 10: 1720-1725.

6. Alemika EEO, Chukwuma IC. Criminal Victimization, Security and Policing in Nigeria. Monograph Series. 2006; No 6. CLEEN Foundation Lagos.

7. Nwawuba SU, Momoh SM, Nwokolo CC, et al. Key DNA profiling markers for identification: A mini review. Pharm Pharmacol Int J. 2020 8: $337-343$.

8. Tjin-A-Tsoi. Trends, Challenges and Strategy in the Forensic Science Sector. Netherlands Forensic Institute. 2013; 1-28. https://www.nist. $\mathrm{gov} /$ system/files/documents/oles/trends-challenges-and-strategy-inthe-forensic-science-sector-march-2013-_tcm120-494231.pdf

9. Heathfield LJ. Policy required for entry of DNA profiles onto the National Forensic DNA Database of South Africa. S Afr J Sci. 2014; 110: 1-3.

10. El-Alfy SH, El-Hafez AF. Paternity testing and forensic DNA typing by multiplex STR analysis using ABI PRISM 310 Genetic Analyzer. J Genet Eng Biotechnol. 2012; 10: 101-112.
11. Nwawuba SU, Okechukwu FC, Momoh SM, et al. The Position of Forensic DNA Database in Criminal Investigation: Understanding the Utilization in Africa, Particularly Nigeria a Review. Int J Foren Res. 2021; 2: 57-66.

12. Nwawuba SU, Akpata CBN. Awareness level on the role of forensic DNA database in criminal investigation in Nigeria: A case study of Benin city. J Foren Sci Res. 2020; 4: 007-014.

PubMed: https://www.heighpubs.org/jfsr/jfsr-aid1019.php

13. Narejo N, Avais MA. Examining the Role of Forensic Science for the Investigative-Solution of Crimes. Sindh Univ Res J (Sci Ser). 2014; 44: 251-254.

14. Oguntunde PE, Oluwadare OO, Okagbue HI, Oguntunde OA. Analysis of selected crime data in Nigeria. Data in Brief. 2018; 19: 1242-1249. PubMed: https://pubmed.ncbi.nlm.nih.gov/30229003/

15. Olonisakin TT, Adedeji JO, Sulaiman OA. The Nigeria Criminal Justice System and Its Effectiveness in Criminal Behaviour Control: A SocialPsychological Analysis. J Human Soc Sci. 2017; 22: 33-34.

16. Alemika EEO. Crime and public safety in Nigeria. CLEEN Foundation. 2014; $1-205$.

17. Tozzo P, Fassina A, Caenazzo L. Young people's awareness on biobanking and DNA profiling: results of a questionnaire administered to Italian university students. Life Sci Soc Policy. 2017; 13: 9.

18. Machado $H$, Silva $S$. Would you accept having your DNA profile inserted in the National Forensic DNA database? Why? Results of a questionnaire applied in Portugal. Forensic Sci Int Genet. 2014; 8: 132-136.

19. Milot E, Marie MJ, Hugo G, Crispino F. The National DNA Data Bank of Canada: a Quebecer perspective. Front. Genet. 2013; 4: 1-7.

20. Wet S, Oosthuizen H, Visser J. DNA profiling and the law in South Africa. PER: Potchefstroomse Elektroniese Regsblad. 2011; 14: 171-207.

21. Orhue K, Omorogbe OS, Ehikhamenor E, et al. Assessment of Knowledge and Perception on The Need for Establishment of Forensic DNA Database in Nigeria. Int J. Inn Eng Res Tech. 2021; 8: 52-57.

22. Machado $\mathrm{H}$, Silva $\mathrm{S}$. What influences public views on forensic DNA testing in the criminal field? a scoping review of quantitative evidence. Hum Genom. 2019; 13: 1-13.

23. Gowsia FK, Sheeba A. Role of Forensic Science in Criminal Investigation: Admissibility in Indian Legal System and Future Perspective. Int J Adv Res Sci Engineer. 2018; 07: 220-234.

24. Obafunwa JO, Ajayi O, Okoye MI. Medical evidence and proof of cause of death in Nigerian courts. Med Sci Law. 2018; 58: 122-134. PubMed: https://pubmed.ncbi.nlm.nih.gov/29381106/

25. Kehinde A. Law and Forensic: Techniques of Evidence Gathering and Case Presentation in Court. Nigeria Village Square. 2020. http://www. nigeriavillagesquare.com/articles/law-and-forensic-techniques-ofevidence-gathering-and-case-presentation-in-court.html

26. Nwawuba SU, Mohammed KA, Adams TB, Precious IO, Davidson EA. Forensic DNA Profiling: Autosomal Short Tandem Repeatas a Prominent Marker in Crime Investigation. Malay J Med Sci. 2020; 27: 22-35. PubMed: https://pubmed.ncbi.nlm.nih.gov/32863743/ 